\title{
THE SECOND SET OF PLAYERS: LAWYERS, FEE SHIFTING, AND THE LIMITS OF PROFESSIONAL DISCIPLINE
}

\author{
Charles W. Wolfram*
}

\section{INTRODUCTION}

The "American Rule," although solidly entrenched, has never been able to boast avid support. The rule insists that a possessor of legal rights should swallow most of the great expense necessary to vindicate them. It strikes many lay and professional observers as unjust. Growth of this sentiment has led to significant judicial and legislative alterations to the American rule. Practitioners of various social sciences and legal specialties_political science, economics, sociology, legal history, comparative law, and others-are marshalled in this symposium to examine the effects and causes of this peculiar American institution and to assess its alternatives.

Many accounts of the operation of fee-shifting systems proceed by considering decisions that might be made by plaintiff and defendant on the assumption that a two-player model adequately describes the principal actors on the fee-shifting or fee-absorbing stage. These accounts are buttressed by professional standards that portray a lawyer-client relationship in which the client calls most of the important shots and the lawyer follows along. Moreover, the lawyer-client fee relationship is idealized as a matter significantly subject to professional constraints against lawyer abuses such as disloyalty, dishonesty, and incompetent or corrupted representation.

A complete analysis of the American rule and suggested alternatives, however, requires consideration of the likehood that these models and ideals of lawyer conduct are incomplete. The lawyer for plaintiff and the lawyer for defendant have interests that can diverge sharply from the interests of the parties they ideally represent. Lawyers, in fact, can exert independent control over such actions as filing suit, settling, and the expenditure of funds, effort, and other critical decisions and moves in a case. Together, divergent lawyer interest and effective lawyer control mean that fee-shifting systems that pay insufficient attention to lawyer motivations and powers can produce surprising and unfortunate consequences. 
This article first examines the lawyer-client relationship from the point of view of congruent or divergent interests in case outcomes as a function of the lawyer's compensation gained through fee shifting. ${ }^{1}$ Second, the article reviews several feeshifting settings in which these divergent interests might lead to lawyers sacrificing their clients' interests or to coercion against lawyers who are conscious of their professional responsibilities. The focus here is primarily upon the two types of problems presented by defendants offering opposing lawyers, who are otherwise entitled to a fee shift, a fee that is similar to either a bribe or an extortion threat. Next, the article suggests reasons why professional constraints on lawyer behavior, constraints that ostensibly assure that fee shifting will not lead to lawyer abuses, probably will not work. The ideals expressed in these professional regulations remain unrealized in real world settings primarily because of difficulties of enforcement, an absence of adequately motivated enforcers, and process constraints on disciplinary agency enforcement of standards for lawyer compensation, honesty, and competence in representing clients. Moreover, it is unlikely that the structure of disciplinary constraints could be reformed sufficiently to obtain effective enforcement of norms for sought-after lawyer behavior in many fee-shifting situations. Therefore, the channeling of lawyer motivation must be accomplished within the structure of the fee-shifting system itself.

\section{II}

\section{Lawyer Divergent Interests and Lawyer Control}

Many current proposals for reform of the American rule seem to proceed on the assumption that inaugurating radical change in the manner in which lawyer fees are paid will not significantly affect lawyers' motivations and loyalties. ${ }^{2}$ Professor Jeffrey O'Connell has recently suggested a legislative or judicial refashioning of personal injury law that would abandon a plaintiff's award of damages for pain and suffering in return for mandatory payment of a successful plaintiff's legal fees by the defendant. ${ }^{3}$ Professor O'Connell, however, does not discuss the possible effects such a fee-shifting arrangement would have on the plaintiff's lawyer. Other studies attempting an economic analysis of fee shifting and related issues have recognized the problem but have been forced to exclude explicit consideration of lawyer divergent interests and lawyer control over suit decisions through explicit, arbitrary assumptions. ${ }^{4}$ As necessary as it is to study parts of the world before synthesizing metaknowledge into more global views, explicit consideration of lawyer motivation and lawyer control might radically alter one's view of the efficacy of proposed fee-shifting devices.

1. The general phenomenon of distinct, and possibly clashing, client and lawyer motivations in litigation recently has received deserved attention. Indispensable is the excellent discussion in Johnson, Lawyers Choice: A Theoretical Appraisal of Litigation Investment Decisions, 15 LAW \& Soc'Y REv. 567 (1980-81). To date, the particular problem of lawyer motivation influenced by fee shifting arrangements has not received attention.

2. E.g., G. Tullock, Trials on Trial: The Pure Theory of Legal Procedure 111-12 (1980).

3. O'Connell, A Proposal to Abolish Defendants' Payment for Pain and Suffering in Retum for Payment of Claimants' Attomeys' Fees, 1981 U. ILL. L. REV. 333, 351.

4. E.g., Shavell, Suit, Settlement, and Trial: A Theoretical Analysis under Alternative Methods for the Allocation of Legal Costs, 11 J. LEGAL STUD. 55, 69 n.50 (1982). 
The chief reason that fee-shifting proposals must take account of lawyer motivation is that lawyers are, among other things, economically motivated agents who can be expected to react to economic stimuli in ways that probably do not vary significantly from the responses of nonlawyers. Clearly, factors other than a desire for fee income may motivate lawyers. Even in the economic realm, fees are not the only "income" that a lawyer earns in representing a client. A lawyer may also put value on less tangible economic goods such as the educational value of a case in teaching the lawyer new skills, its publicity value in attracting other clients to the lawyer, or its value in enhancing the credibility of the lawyer, for example, by gaining the lawyer a reputation as a hardnosed negotiator or as a fairminded and public-spirited individual. ${ }^{5}$ These values can be put into the bank and drawn on in future representations when they will have direct tangible value in producing higher fees than otherwise would be the case. All of these motivations, while indirect and future-regarding, are palpably rational in economic terms.

Lawyers are also swayed by motives that are not economic in any sense, or are even inefficient. Only economists' models (and not many economists) comprehend a world in which all behavior is explained by rational decisions based on calculations of economic costs and benefits. Some of what goes on in litigation seems inexplicable in economic terms. One must resort to psychology and kindred sciences to explain "crazy" economic behavior such as the pathological litigator, the absurdly uneconomic refusal of some high executives in large corporations to testify, and the inability of some lawyers to be prepared sufficiently for litigation. Until economists develop convincing explanations for such profound influences as the impact of alcohol and drugs on lawyer decisions, more than simply economic motivations must be considered because economic motivations provide only partial explanations. Therefore, such considerations as altruism, a personal sense of integrity, an ideologically inspired desire to right certain wrongs, a shared sense of affinity to traditional professional role models honored within the legal profession, and similar influences are detectable behind lawyer attitudes and lawyer decisions on behalf of their clients.

Accepting the above, however, it remains true that most lawyers regard themselves as entrepreneurs and largely act accordingly. These lawyers regard what they are doing as earning a living or better. If a step on behalf of a client causes a decrease in the lawyer's income, this move predictably is regretted and, often, the lawyer attempts to avoid or frustrate such an action. If a step in litigation will increase income, then the average lawyer naturally is under an inducement to take such action and altruistic constraints, at best, will be in contention for the lawyer's loyalty but may not prevail. Consequently, the only apparent restraint on the lawyer's economic self-interest is client control over important moves in the representation. It might be believed that clients can regularly prevent their lawyers from taking steps that are not in the clients' interests but rather are dictated by lawyer self-interest in obtaining fees under fee-shifting arrangements. Client con-

5. See Johnson, supra note 1 , at $580-82$. 
trol, however, probably does not work effectively and, actually, is unlikely to occur in fee-shifting situations.

The professional model, to be sure, is one of effective and informed client control. The professional ideal is that lawyers will continually keep their clients informed of important developments in the litigation, ${ }^{6}$ inform them of relevant legal and nonlegal factors that bear upon upcoming moves, ${ }^{7}$ and abide by client decisions with respect to all important aspects of the case. ${ }^{8}$ If the interests of the client and lawyer diverge in any material way, the lawyer is under a professional obligation to proceed no further unless the client, after being fully informed, consents. 9 These professional obligations are undergirded by obligations of total loyalty to a client and dedication of both intense interest and considerable skill to the client's objectives. ${ }^{10}$

The professional model, however, might be a tapestry of professional mythology. Many parts of the model are revealed as fictive by scholars who define a very different picture in many areas of representation and as courts themselves make inroads. Scholars who study the legal profession have been reporting for some time that lawyers regularly depart from the professional model of client control and make critical decisions on their own in both criminal ${ }^{11}$ and civil represen-

6. Model Code of Professional Responsibility EC 7-8 (1981) [hereinafter cited as MoDel Code]; Model Rules of Professional Conduct Rule 1.4 (Aug. 1983) [hereinafter cited as 1983 MOdel Rules]. The Model Code has been adopted verbatim or to a substantial extent as the professional regulatory rules for lawyers in most jurisdictions. The "EC" citation identifies an aspirational guide while "DR" identifies a rule which is mandatory and for violation of which a lawyer may be disciplined. See MODEL CODE, supra, Preliminary Statement.

The Model Rules were adopted by the ABA, in August 1983, to replace the Model Code. They will not be effective unless adopted in individual jurisdictions.

7. MODEl CODE, supra note 6, EC 7-8 (1983); 1983 MODEL Rules, supra note 6, Rules 1.2(a), 1.4(b).

8. MODEL CODE, supra note 6, EC 7.7 ("In certain areas of legal representation not affecting the merits of the cause or substantially prejudicing the rights of a client, a lawyer is entitled to make decisions on his own. But otherwise the authority to make decisions is exclusively that of the client."); see, e.g., Wilder v. Third Dist. Comm. of the Va. State Bar, 219 Va. 175, 179, 247 S.E.2d 355, 358 (1978) (decision whether to pursue judgment against defendant that lawyer thinks is judgment-proof is one to be made solely by client); see also MODEL CODE, supra note 6, EC 7-8; $f$. 1983 MODEL Rules, supra note 6, DR 7 101(A)-(1). Attempts are sometimes made to draw distinctions between tactical and strategic decisionmaking, with problematic results. E.g., Burger, Standards of Conduct for Prosecution and Defense Personnel: $A$ Judge's Viewpoint, 5 AM. CRIM. L.Q. 11, 51 (1966); Roscoe Pound-Am. Trial Lawyers Ass'n, Final Report: Ethics and Advocacy 14-16 (1978).

The ABA's Model Rules take a twofold approach: "A lawyer shall abide by a client's decisions concerning the objectives of representation . . . and shall consult with the client as to the means by which they are to be pursued." 1983 MODEL Rules, supra note 6, Rule 1.2(a).

9. MODEl CODE, supra note 6, EC 5-3 (1981).

10. Id. EC 5-1, 7-1; 1983 MODEL Rules, supra note 6, Rules 1.3, 1.7

11. The picture in criminal defense representation is one of rather complete lawyer domination even of such critical decisions as whether to plead guilty. Alschuler, The Defense Attomey's Role in Plea Bargaining, 84 YALE L.J. 1179, 1306 (1975) (interviews reveal that normal defense counsel attitude is that clientaccused must accept bargain negotiated by lawyer or find new representation); Blumberg, The Practice of Law as a Confidence Game: Organizational Cooptation of a Profession, 1 LAW \& SOC'Y REv. 15, $24-28$ (1967) (lawyer manipulation of client accused in order to justify fee while maximizing lawyer profit). See Skolnick, Social Control in the Adversary System, $11 \mathrm{~J}$. Conflict Resolution 52, 65 (1967) (in the lawyer-client relationship, the lawyer usually regards himself as the "player").

Lawyers occasionally candidly reject, at least implicitly, the professional model of client control. E.g., Nadjari, Panel Discussion: Professional Responsibility in the Practice of Criminal Law, The Murky Divide Between Right and Wrong, in Professional Responsibility of the LaWyer 58 (N. Galston ed. 1977) ("It's self-evident to me that capable attorneys control their [criminal] clients."). 
tations. ${ }^{12}$ The studies indicate that many lawyers give little deference to clients on such critical matters as when to settle a case and how vigorously to contest it. ${ }^{13}$ The sources of lawyer power in the relationship are many and complex, but chiefly consist of information monopolies, better access to levers of effective power such as judges and court officials, and skill in negotiating with clients through threats, dire forecasts of probable alternative outcomes, and similar psychological pressures. ${ }^{14}$

Much lawyer departure from the professional model of lawyer submission to client control occurs because of the fee incentives under which lawyers work. The same deviations from the model can occur in lawyer payment systems that involve no fee shifting. For example, the hourly rate method of compensating a lawyer provides a lawyer with an incentive to prolong litigation in order to churn out hours and fee claims against the client. ${ }^{15}$ Studies of the operation of such feeshifting devices as the contingent fee ${ }^{16}$ and the "lodestar" system of awarding fees when courts have been empowered to make such awards under exceptions to the American rule ${ }^{17}$ offer powerful reasons for concluding that lawyer motivation comes under strong and corrupting influence due to the prospect of winning or increasing a fee award.

12. A high degree of effective lawyer control is probably present in many noncriminal situations when the client is economically weak, the precise situation in which many fee-shifting proposals seek to enhance the client's litigating posture by funding his lawyer. E.g., D. Rosenthal, LaWyer and CliENT: WhO's In Charge? (1974) (personal injury plaintiffs); Hostika, We Don't Care About What Happened, We Only Care About What Is Going to Happen: Lawyer-Client Negotiations of Reality, 26 SoC. ProBs. 599 (1979) (legal service clients); Macaulay, Lawyers and Consumer Protection Laws, 14 LAW \& SOC'Y REV. 115, 128, 159-60 (1979) (consumer clients).

Lawyer domination in noncriminal cases can take extreme forms of attempted autocratic control. By way of possible illustration, in People ex rel. Attorney Gen. v. Beattie, 137 Ill. 553, 556, 27 N.E. 1096,1099 (1891), the court quoted the following from a letter to a disgruntled client by a lawyer who was disbarred for suborning perjury of other witnesses:

If you are here on Saturday next, you will have your [divorce] decree. If you are not here, it is no fault of mine. However, it may be as well to understand that $I$ never suffer any scolding or dictation from my clients. I know better how to conduct their cases than they do, and I conduct my cases my own way.

13. D. Rosenthal, supra note 12; Spiegel, The New Model Rules of Professional Conduct: Lawyer-Client Decision Making and the Role of Rules in Structuring the Lawyer-Client Dialogue, 1980 AM. B. FOUND. RESEARCH J. 1003,1003 n.3.

14. See generally authorities cited supra notes 11-12; E. Freidson, Professional Dominance (1970); Mazor, Power and Responsibility in the Atlomey-Client Relationship, 20 STAN. L. REV. 1120 (1968).

15. See, for example, Rosenblatt v. Ocean Controls Corp., 188 N.Y.L.J. 17 (1982), in which a fine of $\$ 400$ was levied against a defendant's lawyer for a frivolous argument made in oppostion to a routine motion. The court held that the fine was to be paid by the offending lawyer unless the court's inclination to find bad faith could be rebutted on a further hearing. Among other things, the court suggested that a finding of no bad faith could be readily supported if it developed that the offending lawyer's fee agreement with his client did not call for an hourly fee charge.

16. The principal studies are Mitchell \& Schwartz, Theoretical Implications of Contingent Legal Fees, 12 Q. Rev. Econ. \& Bus. 69 (1972); Schwartz \& Mitchell, An Economic Analysis of the Contingent Fee in PersonalInjury Litigation, 22 STAN. L. REv. 1125 (1970); and Clermont \& Currivan, Improving on the Contingent Fee, 63 CORNell L. REv. 529 (1978). Some scholars nonetheless do assume strong client control of decisions in contingent fee settings, regardless of the impact of client decisions on lawyer income. Such an assumption, for example, must underlie arguments that the contingent fee contract promotes unwanted litigation because it encourages speculative, frivolous, or otherwise nonmeritorious cases with a low probability of a large payoff. See Halpern \& Turnbull, An Economic Analysis of Legal Fees Contracts, in LAWYERS AND THE Consumer Interest: Regulating the Market for Legal Services 161 (1982).

17. See Leubsdorf, The Contingency Factor in Altorney Fee Awards, 90 YaLE L.J. 473 (1981). 
To some extent, courts have worked independent lawyer motivation and outcome control into the fabric of accepted procedure. This incorporation has occurred in the important area of class actions where settlements are subject to judicial approval and disapproval. ${ }^{18}$ Federal courts have recently held: (1) that a settlement proposal supported by class counsel could be approved by the court despite the fact that the named class representative vehemently opposed it; ${ }^{19}$ (2) that a class action settlement supported by the class representative could be approved by the court even though it was opposed by class counsel; ${ }^{20}$ and (3) that a fee-shifting statute provided a right to recover a fee on the part of the lawyer so that a client's private settlement of an action could not deprive the lawyer of his right to recover the fee. ${ }^{21}$ Only the second of these holdings comports with the traditional view that clients, and not their lawyers, control the effective disposition of the case $\mathrm{e}^{22}$ and that clients are the source to which lawyers normally should look for the payment of their fees. ${ }^{23}$ The holdings portray an entirely radical regime in which effective control over the disposition of class actions has shifted, clearly to the judge and arguably to the defendant, who to an extent can play one player (the lawyer or the client class representative) off against the other. The defendant's ability to take advantage of the situation is impaired to some extent by rules prohibiting direct communication between the defendant's lawyer or the defendant and the opposing party. ${ }^{24}$ But if these communication barriers can be overcome, then the plaintiff's lawyer has lost some part of the advice-giving influence over the client that the traditional model also assumed. ${ }^{25}$ Perhaps of even greater importance, the former power that a client could wield over his or her lawyer because of client control over fee payment has been almost entirely stripped away in many fee-shifting situations. As a result, the way is open for direct negotiations between the plaintiff's lawyer and the defense, and their resulting agreements can be presented to the court for approval despite the objections of the only person who - if we adhere to the formalities of class actions ${ }^{26}$-is empowered to bring the action in the first place.

The apparent justification for this loosened client control-and arguably an adequate substitute for it-is the greatly enlarged role of the presiding judge. The judge can effectively veto a proposed settlement if not persuaded that it is in the best interests of the larger community of persons and interests affected by it, including those who are objecting, presumably misguidedly. Whether judges can

18. E.g., FED. R. CIV. P. 23(e) (class action "dismissal or compromise" subject to judicial approval after notice to class); see also FED. R. CIV. P. 23.1 (derivative actions). The federal procedural rules on class actions have been widely followed in state court procedural rules. See 1 H. New'Berg, Cl.ASs ACTIONS $\S 1220$, at 294 (1977 \& Supp. 1978).

19. E.g., Parker v. Anderson, 667 F.2d 1204, 1211 (5th Cir. 1982); McDonald v. Chicago Milwaukee Corp., 565 F.2d 416, 426 (7th Cir. 1977); Saylor v. Lindsey, 456 F.2d 896, 899-900 (2d Cir. 1972).

20. See In re Federal Skywalk Cases, 97 F.R.D. 370,377 (W.D. Mo. 1983) (dicta).

21. See James v. Home Constr. Co., 689 F.2d 1357 (11th Cir. 1982).

22. See supra text accompanying notes 6-10.

23. Cf. MODEl CODE, supra note 6, DR 5-107(A)(1).

24. Id. DR 7-104(A); 1983 MODel Rules, supra note 6, Rule 4.2.

25. See supra text accompanying notes 6-7.

26. The logic, rather than the formality, of class action law suggests that it might do in some instances to permit lawyers to bring class actions without an initial client. See Kalven \& Rosenfeld, The Contemporary Function of the Class Suit, 8 U. CHI. L. REv. 684, 718 n.98 (1941). 
play or in fact do play such a large role may be seriously doubted. Certainly, the high unlikelihood that a judge will veto a proposed plan of settlement suggests that the judicial veto is reserved only for the most blatant ripoff of a class. ${ }^{27}$

Similar judicial erosion of the client-control model is visible in related doctrinal developments concerning fee awards outside the class action area. Courts tend toward a view that a fee award under a fee-shifting statute is not subject to the control of the lawyer's client but, in some sense at least, "belongs" to the lawyer. Thus, a fee award to the lawyer for a prevailing party cannot be subjected to setoff against the plaintiff's indebtedness to the defendant on a counterclaim. ${ }^{28} \mathrm{~A}$ lawyer denied a fee application has standing to appeal. ${ }^{29}$ Further, when a settlement is achieved behind the plaintiff's lawyer's back by a Truth-in-Lending defendant, the plaintiff cannot preclude the lawyer from later asserting a claim for fees under the fee-shifting provisions of the statute. ${ }^{30}$

These developments are explicable on the ground that the policy objectives of fee-shifting arrangements will be frustrated if lawyers are given less control and management of the fee question. But it should also be apparent that the loosening or removal of client control over the purse strings that regulate the flow of income to the lawyer creates the risk that the lawyer might engage in unwanted, harmful conduct.

\section{III}

\section{THE Prandini Solution}

If one accepts that real-world lawyers, either deviantly or with judicial encouragement in some areas, are functioning independently of client control with respect to significant moves in litigation, what specific threats does this portend to the goals sought to be achieved through fee shifting? ${ }^{31}$ And to what extent might fee shifting exacerbate existing temptations for lawyers to engage in unwanted behavior? A prominent illustration of ways in which fee-shifting objectives can be frustrated by the fee-benefited lawyer is portrayed by the Prandini $v$. National Tea Co. ${ }^{32}$ decision, which has become well-known and controversial ${ }^{33}$ for its rule that

27. Statistics on judicially rejected settlements seem not to exist. This view is an impressionistic one gained from following class actions and from an inability to find very many reported cases in which a settlement was rejected by a judge. The absence of reports does not mean that judges have not much less formally-but equally effectively-signalled to negotiating lawyers that an acceptable settlement must provide greater relief to the class than that being discussed or tentatively proposed. Class actions are typified by a great deal of off-the-record chambers conferences that make chronicling their course from printed records a very chancy business.

28. E.g., Plant v. Blazer Fin. Servs., Inc., 598 F.2d 1357 (5th Cir. 1979); General Inv., Inc. v. Thomas, 422 So. 2d 1279 (La. App. 1982).

29. Lipscomb v. Wise, 643 F.2d 319 (5th Cir. 1981).

30. James v. Home Constr. Co., 689 F.2d 1357 (11th Cir. 1982). The rationale of the court is quite germane. The court emphasized that fee awards were a "critical and integral" part of the congressional scheme of private attorney general enforcement under the Federal Truth in Lending Act, that relatively indigent clients had no economic incentive not to accede to attractive offers to bargain away their lawyer's fee-award claim, and that lenders should not be able to readily evade the private enforcement and remedial schemes of the legislation.

31. These goals have been catalogued and analyzed in Rowe, The Legal Theory of Altomey Fee Shiffing: A Critical Overview, 1982 DuKE L.J. 651.

32. 557 F.2d 1015 (3d Cir. 1977).

33. Some courts have rejected Prandini. E.g., Folsom v. Butte County Ass'n of Gov'ts, 32 Cal. 3d 668, 
in actions involving a court-awarded fee the lawyers are not to negotiate or discuss the fee award as part of settlement discussions. These negotiations may take place only after the court approves the damage settlement. ${ }^{34}$

Prandini is often thought of as one problem, but in fact it is two. The commonly discussed concern is that portrayed in Prandini itself: that the lawyer for the plaintiff might have been induced to support a very low settlement offer because of its generous fee allowance, ${ }^{35}$ a "sweetheart contract" for the lawyer but not the client. ${ }^{36}$ Prandini-sweetheart offers are made more often in plaintiff class actions, with greater discounts applied to the portion of the settlement that would go to the plaintiff class, because of the rule that a settlement supported by the class lawyer can be approved by the court notwithstanding objections from the class members. ${ }^{37}$ Sweetheart offers can also be employed when the client retains ultimate power to accept or reject any settlement offer-for example, in an individual damage suit for sex discrimination in employment-but there it would be necessary to keep the client uninformed or otherwise mollified about the relatively small size of his or her portion of the proposed settlement.

The second and less-discussed variation on the Prandini problem is the result of reverse leverage applied by the defendant; instead of a generous offer to the lawyer and a paltry one to the client, the defense offers generous terms to the client and

681, 652 P.2d 437, 446, 186 Cal. Rptr. 589, 598 (1982); see also A. Miller, Attorneys' Fees in Class ACTIONS 222-23 (1980) (criticisms of Prandini, but poll of federal judges and practitioners shows wide support for rule).

34. See Prandini, 557 F.2d at 1021 (3d Cir. 1977). A controversial provision of the Corporate Governance project of the American Law Institute would make Prandini the mandatory practice in shareholder litigation. See Principles of Corporate Gover nance and Structure: Restatement and RecomMENDATIONS $\S 7.07$ (b) (Tent. Draft no. 1, 1982) [hereinafter cited as PRINCIPLES OF CoRPORATE GOVERNANCE]: "Until such time as the court having jurisdiction over the action has approved a proposed settlement, none of the parties, their attorneys or agents shall enter into any agreement, negotiation or discussion concerning allowable plaintiff's fees or expenses with an opposing party in the action

Some courts have accepted Prandini as a general rule, but have approved settlements negotiated in violation of the fee-discussion prohibition because of independent guarantees that the class' interests likely were not compromised as a consequence of the class lawyer's interest in receiving a large fee award. E.g., Mendoza v. United States, 623 F.2d 1338 (9th Cir. 1980) (intervention of Department of Justice on behalf of plaintiff class protected the class from lawyer's possible conflict because of simultaneously negotiated fee award), cert. denied, 450 U.S. 912 (1981).

35. It is well documented in other contexts that lawyers and their clients may have radically different incentives when presented with a settlement offer. For the lawyer, the chance to obcain a "quick kill" and a sure fee might be very tempting, while a well-advised client would view the settlement without a similar degree of enthusiasm or anxiety. See Dam, Class Actions: Efficiency, Compensation, Deterrence, and Conflict of Interest, 4 J. Legal STud. 47, 57 (1975) (class actions); Schwartz \& Mitchell, supra note 16 (contingent fees). The point being made here assumes that risk-neutral and well-informed lawyers and clients would regard the lawyer's fee award and the client's substantive relief offered in the settlement as grossly disproportional.

36. See Prandini, 557 F.2d at 1021. The "sweetheart contract" problem has been recognized by many courts, although not always by the "sweetheart" appellation applied in Prandini itself. E.g., Obin v. District No. 9, Int'l Ass'n of Machinists \& Aerospace Workers, 651 F.2d 574, 582 (8th Cir. 1981); Mendoza v. United States, 623 F.2d 1338, 1352-59 (9th Cir. 1980), cert. denied, 450 U.S. 912 (1981); Pettway v. American Cast Iron Pipe Co., 576 F.2d 1157, 1216 n.71 (5th Cir. 1978) (dicta), cert. denied, 439 U.S. 1115 (1979); City of Detroit v. Grinnell Corp., 495 F.2d 448 (2d Cir. 1974); Regalado v. Johnson, 79 F.R.D. 447,451 (E.D. Ill. 1978).

37. See supra text accompanying note 19. 
little or nothing to the lawyer ${ }^{38}$ A fillip that can make the offer sting more is to condition the offer expressly on the lawyer's explicit agreement to accept a low or no fee. ${ }^{39}$ Fee leverage thus can operate in the hands of the defendant either as a bribe or as extortion, referred to herein as Prandini-sweetheart offers and Prandiniextortion offers.

These distorting devices occur in different settings and involve different lawyer motivations, although they share salient features and perhaps can be dealt with through the same judicial or legislative approach. Prandini-sweetheart offers involve lawyer motivation to support a settlement that an "objective" lawyer would urge a client to reject. A Prandini-extortion offer puts pressure on the lawyer to oppose a settlement that is quite generous to the lawyer's client but which offers a fee award that an "objective" lawyer would regard as inadequate.

These devices share at least two characteristics. First, to the extent that they are effective, it is because of the divergent economic interests of client and lawyer. Each is motivated to contend against the other, or at least to neglect the interests of the other, in order to maximize his or her own gain. Second, the "net" result is probably dysfunctional to important purposes of fee shifting, at least in the long run. In the short run, if one focuses solely on the individual settlement, full restitution and deterrent impact ${ }^{40}$ might be imposed on the defendant because of the enhanced damage award or lawyer fee award that defendant must offer in order to obtain the desired leverage. The size of the premium depends on such variable matters as the relative risk aversion of lawyer and client, the relative amounts and kinds of information and advice that each is receiving, and the extent to which judicial approval of the settlement, if required, or other external regulation takes an active or passive form. In the long run, however, the defendant, particularly if the practice can be resorted to predictably in the future, can "buy out" of the statutory and judicial protections and policies that fee shifting and the substantive law underlying the plaintiff's claim are designed to enforce.

Prandini-sweetheart settlements, if permitted, involve defendants buying out plaintiff's lawyers with the effect of defeating full recovery for victims and full deterrence of the illegal activity that gave rise to the lawsuit in the first place. Prandini-extortion settlements, if permitted, provide predictably strong disincentives to lawyers and others to enter into future litigation in which Prandini-extortion offers can be made. Ultimately, the fee shifting provided in federal civil rights cases, for example, will be defeated to the extent that it was designed to encourage

38. Reportedly, these offers are made with great regularity in civil rights and civil liberties litigation See Levin, Practical, Ethical and Legal Considerations Involved in the Settlement of Cases in Which Statutory Attomey's Fees Are Authorized, 14 ClearinGHOUSE REV. 515, 515 n.7 (1980) ("Virtually every legal services attorney involved in consumer cases has been confronted with such offers."); Fee Waiver Requests Unethical: Bar Opinion, 68 A.B.A.J. 23 (1982) (staff counsel to American Civil Liberties Union estimates that more than half of civil rights cases litigated see such offers). A reported case apparently involving such an offer is Krause v. Rhodes, 640 F.2d 214 (6th Cir. 1981), cert. denied, 454 U.S. 836 (1981). The court in Krause approved a settlement offer that was conditioned on a very low attorney fee award, apparently on the sui generis ground that this deeply divisive litigation arising out of the tragic Kent State killings by members of the National Guard should be put to rest.

39. Rhode, Class Conflicts in Class Actions, 34 STAN. L. REv. 1183, 1207 (1982).

40. See Rowe, supra note 31 , at 660-61. 
lawyers to champion cases involving civil rights claims. ${ }^{41}$ In quite different ways, both Prandini-sweetheart and Prandini-extortion offers have this policy-nullifying effect.

\section{IV \\ Other Unwanted Lawyer Conduct}

Before turning to a consideration of the way that the organized bar has responded to the professional problems presented by Prandini offers, it is advisable to expand our scope to examine, briefly, other types of unwanted lawyer conduct that can be motivated by forms of fee shifting. Indeed, Prandini-type problems may not be the abuses most disruptive of the goals of fee-shifting arrangements.

Lawyer fraud might be a more costly abuse across the entire sweep of cases in which the law provides for fee shifting. Fee shifting in many of its forms presents opportunities for lawyer self-advancement through misreporting of effort. Under the widely employed "lodestar" method of computing a fee award, based largely on the number of billable attorney hours, lawyers are under strong economic pressure to work slowly or to perform work that is unnecessary. ${ }^{42}$ Beyond goldbricking, outright falsification of hours is suspected. ${ }^{43}$ Unless the attempt is blundered, these fabrications are difficult to detect because hours worked is a matter of self-reporting and is not subject to effective verification. ${ }^{44}$ In addition, other bases for the fee can be falsified. Lawyers whose previous clients have been limited largely to those normally requiring low-paying work, such as personal injury and misdemeanor representations, make claims in fee-shifting cases that their "normal" hourly charge is $\$ 150$ or more. (At the least, one may wonder why lawyers with such prosperous practices leave them and pursue fee-shift cases that hold the risk of no fee; pursuit of the public interest surely does not explain all the instances.) Sometimes, possible frauds are ignored because the fee will be paid out of a settlement pot in which no party capable of mounting an attack on the fee is

41. See id. at 663 .

42. E.g., A. Miller, supra note 33, at 270-71 (1980); Coffee, Rescuing the Private Altorney General: Why the Model of the Lawyer as Bounty Hunter is Not Working, 42 MD. L. REv. 215, 247 (1983); see also In re Fine Paper Antitrust Lit. 98 F.R.D. 48, 68, 85 (E.D. Pa. 1983) (\$20,200,000 in requested legal fees reduced nearly $\$ 16,000,000$ : "These fee petitions are grossly excessive on their face. . . I regret to say that my inquiry has given substance to the worst fears of the critics of the class action device-that it is being manipulated by lawyers to generate fees.").

43. E.g., In re Fine Paper Antitrust Lit., 98 F.R.D. 48, 172, 177-78 (E.D. Pa. 1983); A. Millek, supra note 33, at 275-76 (one-third of surveyed judges and lawyers believed that inflating timesheets was common practice).

44. The dogged pursuit of the question of falsified hours in In re Fine Paper Antitrust Lit., 98 F.R.D. 48 (E.D. Pa. 1983), seems to be sui generis. After class lawyers filed fee requests for almost $40 \%$ of the preinterest class recovery, several large corporate class members hired a New York law firm to investigate and resist fee claims. A fratricidal dispute broke out among the plaintiffs' lawyers about fee shares, causing several lawyers to expose irregularities of others. See Bruck, Harold Kohn Against the World, Am. LAw., Jan. 1982, at 28; Bruck, Reading Moody's for 8682 An Hour, AM. LAw., Jan. 1982, at 31. The presiding judge held hearings that consumed four months and eventually issued a 189-page opinion. The circumstances suggest that detection of the falsification could readily have been avoided by a more efficient and nonpublic negotiation of intraclass leadership and fee disputes, a development which seems predictable in many future cases. The commitment of resources by class members and courts to the question of the size of fees also seems atypical although, given the magnitude of the amounts at stake, not at all inappropriate. 
present in court to do so. ${ }^{45}$

Fee-splitting and kindred practices probably are rather widely engaged in by plaintiff's lawyers in certain clientless litigation such as class actions for damages in which the "fund theory" will be invoked for an award of fees. Related practices include rather blatant and self-interested "brokering" of power positions in one case in return for power in another-always with a larger share of the fee award ultimately in view. ${ }^{46}$

American professional standards also carry implications for two-way fee shifting. For example, Federal Rule of Civil Procedure 37(a)(4) provides that a lawyer advising a client to disobey a discovery order can, in the court's discretion, be ordered to pay an attorney fee to the opposing party. ${ }^{47}$ For some time, applicable professional standards have prohibited a lawyer from advancing or guaranteeing financial assistance to a client in connection with contemplated or pending litigation. ${ }^{48}$ It appears that a court-imposed obligation to pay the legal fees of an aggrieved opposing party would not constitute a violation of these professional rules. But that hardly exhausts the subject.

Quite conceivably, a lawyer might recommend a course of action with the assurance to a client that any penalties that might befall him would be paid by the lawyer. Even in the absence of such an explicit understanding, the purpose of the professional standards may be compromised to some extent by the judicial power to impose fee costs on a lawyer. The major purpose behind the prohibition against cost advancement is rooted in the common law prohibitions against such litigation-supporting maneuvers as champerty, barratry, and maintenance. The modern expression of purpose is that a lawyer's advancement of costs to a client puts the lawyer in the position of one who has an undue economic investment in the outcome of the litigation. This interest, it is feared, will impair the professional detachment of the lawyer. ${ }^{49}$ A similar impairment may occur when a lawyer is ordered to pay the fees of an opposing party. Nonetheless, the goals sought to be served by punitive assessments of fee costs for bad faith litigation probably cannot be achieved without incurring some possibility of conflict of interest. On the other hand, the lawyer abuses involved in such practices as the Prandini-sweetheart and Prandini-extortion settlements apparently require regulation.

45. The peculiar arrangements of typical "fund" theory fee shifting leave a defendant devoid of any interest in the distribution of a settlement fund once it has been accepted by the court. Often, the claimants against the fund are too numerous and too uninformed and have claims too small to permit effective scrutiny of the size of the lawyer fees that consume a large part of their fund before they see its remnants. See A. Miller, supra note 33, at 204; Dawson, Lawyers and Involuntary Clients: Attomey Fees from Funds, 87 HARV. L. REV. 1597 (1974).

46. Coffee, supra note 42 , at 59,61 .

47. FED. R. Civ. P. 37(a)(4). The Federal Rules were amended in 1983 to extend considerably the power of federal judges to impose fee-paying obligations on lawyers who take or advise clients to take certain unwanted steps in litigation. See FED. R. CIV. P. 11, 16(f), 26(g) (amended 1983).

48. This sentence is a paraphrase of the MODEL CODE, supra note 6, DR 5-103(B). Compare 1983 MODEL RULES, supra note 6, Rule 1.8(e).

49. See 1983 MODEL Rules, supra note 6, Rule 1.8(e), comment. 


\section{V \\ Lawyer Codes and Fee Shifting Abuses}

A well-tempered reflex of lawyers and judges confronted with an instance of lawyer misfeasance is to apply or create professional standards enforceable through agencies of professional discipline. Therefore, one might inquire whether Prandinisweetheart offers or Prandini-extortion offers or other lawyer behavior influenced by fee shifting raise problems under the lawyer disciplinary codes. The answer is that professional regulations bear rather plentifully, and disapprovingly, on many of the problems discussed but only debatably on others.

The Prandini -sweetheart dealing is an ethical sitting duck. It plainly falls under those provisions of the lawyers' rules which proscribe disloyalty to a client ${ }^{50}$ and engaging in activity that creates an impermissible conflict of interest without the informed consent of the client. ${ }^{51}$ The conflict of interest is created because the plaintiff's lawyer's temptation to receive a large fee creates strong economic pressure not to assure that the client receives the maximum possible settlement award. This, in turn, creates pressures for the lawyer not to inform the client fully and fairly about the alternatives to acceptance of the settlement. ${ }^{52}$ The disparities between the lawyer's proposed fee and the client's proposed award might be so great that the conflict becomes "nonconsentable" and cannot be cured even through client consent. ${ }^{53}$ More problematically, the defendant's lawyer may be in

50. Model CODE, supra note 6, EC 5-1; 1983 MOdel Rules, supra note 6, Rule 1.7, comment.

51. MODEl CODE, supra note 6, DR 7-101(A)(1) ("A lawyer should not intentionally. . . fail to seek the lawful objectives of his client through reasonably available means . . . ."); 1983 MODEL RULEs, supra note 6, Rules 1.7, 1.8. Also apparently implicated is MODEL CODE, supra note 6, DR 7-107(B) ("A lawyer shall not permit a person who pays him to render legal services for another to direct or regulate his professional judgment in rendering such legal services."). Cf., e.g., Kramer v. Scientific Control Corp., 534 F.2d 1085 (3d Cir. 1976) (lawyer for the class may not be named as the class representative because of feegenerated conflict), cert. denied, 429 U.S. 830 (1976); Munoz v. Arizona State Univ., 80 F.R.D. 670,671 (D. Ariz. 1978) (lawyer who sought to negotiate his fee simultaneously with the merits would not be adequate counsel for the class); Note, Developments in the Law-Conflicts of Interest in the Legal Profession, 94 HaRV. L. REV. 1244, 1454 (1981).

52. The legal profession's method for dealing with conflicts of interest calls for a lawyer to recognize conflict-of-interest situations at the outset, requires that the lawyer not proceed with the representation once a serious conflict has been detected unless the client consents, and threatens professional discipline (ranging from private reprimand to disbarment) for failure to comply with either of the preceding two steps. Clearly, this arrangement is not fully protective of the client in the context of either form of the Prandini problem. In Prandini-sweetheart situations, an important economic control that a client usually can exert over a lawyer with divergent interests is missing precisely because the lawyer is looking to a third party, and not to the client, for fee payment. Moreover, it is just at the moment when the client wishes to have dispassionate and objective advice about the nature, extent, and possible consequences of the lawyer's conflict of interest and about the adequacy of the settlement offer that the lawyer is staggering under the weight of a very generous fee allowance offer. Driven by conflicting interests in professional integrity and a desire for handsome remuneration, the lawyer is in a poor position to recognize the extent of the conflict and give the client full and adequate advice about how to assess the lawyer's advice in light of that conflict. Finally, in many Prandini situations, the "client" is a nominal party in a class action and has little economic or other incentive to control the lawyer's behavior. E.g., Rhode, supra note 39, at 1212-15.

53. The concept of the nonconsentable conflict is an emerging one. The Model Code of Professional Responsibility explicitly recognizes it only in the context of simultaneously representing clients with adverse interests. MODEL CoDE, supra note 6, DR 5-105(C) (in conflict of interest representations, client consent can be given only "if it is obvious that [the lawyer] can adequately represent" the interests of each client and each client consents after full disclosure); e.g., Kesselhaut v. United States, 555 F.2d 791, 794 (Ct. Cl. 1977) (former government lawyer conflict not cured by former client's consent when conflict is "flagrant"); 
violation of professional rules for inducing another lawyer to act disloyally to his or her client. ${ }^{54}$

The permissibility of Prandini-extortion offers is primarily a question of the behavior of the defendant's lawyer. The defense lawyer seeks to gain an advantage by conditioning a favorable settlement on the adversary lawyer's fee waiver. The gambit will be succesful only if the opposing lawyer resists the economic temptation created by the offer to advise the client unwisely to reject the settlement. According to an ethics opinion of the Association of the Bar of the City of New York, a defense lawyer in a case involving a civil rights or civil liberties claim commits a violation of the Code of Professional Responsibility if he exacts or enters into discussions about a Prandini-extortion settlement offer. ${ }^{55}$ The committee's rationale is that Prandini-extortion offers seriously impinge on the policies behind civil rights statutes providing fee awards-those policies of providing compensation to victims of discriminatory conduct and of deterring its repetition. ${ }^{56}$ Although the opinion repeatedly stresses that it is limited to fee shifting in civil rights and civil liberties cases, ${ }^{57}$ its reasoning may not be so easily cabined; the policy of providing counsel to those unable to afford suit if not benefited by fee shifting underlies many important statutes not related to civil rights and civil liberties.

The City Bar opinion can be questioned from several points of view, but one criticism seems particularly telling. The fundamental anomaly in the committee's

In re Mercer, 133 Ariz. 391, 394, 652 P.2d 130, 133 (1982) (lawyer disbarred for providing legal services to client in client's sale of property to partnership in which lawyer was general partner; client's alleged consent was unavailing because conflict was nonconsentable). The ABA's 1983 Model Rules limit all conflicttype consents to situations in which a lawyer reasonably believes that the client's interests will not be "adversely affected." 1983 MODEL RULES, supra note 6, Rule 1.7(b)(1).

54. The situation is closely analogous to the crime of bribery, and the conduct of the defendant's lawyer lacks only the element of inducing an act by a public official to bring it squarely within laws proscribing offering a bribe. The conduct would seem to fit more comfortably within the commercial bribery concept accepted in some jurisdictions. See D. DOBbs, HandBoOK on THE LaW OF Remedies $\S 10.6$, at 701 n.8 (1973); see also MODel Penal CODE $\S \S 224.8(1)$ (c), 224.8(2) (1980) (lawyer commits misdemeanor if "he solicits, accepts or agrees to accept any benefit as consideration for knowingly violating or agreeing to violate a duty of fidelity to which he is subject"; person who makes offer similarly liable). Even if not criminal, the attempt to bribe an agent falls afoul of common-law agency rules. See RESTATEMENT (SECOND) OF AGENCY $§ 312$ (1958).

55. Op. 80-94, 36 Rec. A.B. CrTY N.Y. 507 (1981). The opinion was resisted by a "substantial minority" of the Committee on Professional and Judicial Ethics. Id. at 510. The rationale of the majority is quite puzzling in several respects. (1) To the extent that the opinion is based on MODEL CODE, supra note 6, DR 1-102(A)(5) (a lawyer shall not "engage in conduct that is prejudicial to the administration of justice") and id. EC 2-25 ("Every lawyer should support all proper efforts to meet [the] need for legal services [on the part of those unable to pay reasonable fees]."), would it be unethical for a lawyer to advocate a limiting construction of a fee-award statute or to urge its repeal? (2) Is the opinion limited to plaintiff's lawyers who operate out of "public interest organizations"? See Op. 80-94, 36 REC. A.B. CITY N.Y. 507, 508 (1981). (3) Why is the "public policy" rationale limited to cases in which fee shifting is provided in actions involving civil rights and civil liberties instead of being generally applicable to fee shifting statutes involving otherwise indigent claimants? (4) Are "fair" fee awards the proper subject of presettlement discussions?

56. Op. 80-94 Rec. A.B. Ciry N.Y. 507, 510 (1981): "[T] the waiver of statutory fees is to prejudice a vital aspect of the administration of justice and undermine efforts to make counsel available to those who cannot afford it, contrary to the obligations and aspirations of the Code of Professional Responsibility."

57. Id. at $507,508,509,511,512$ n. 4 . 
reasoning is that it treats as "unethical" conduct on the part of a lawyer which, from all that appears in the opinion, is perfectly legal for the client (the defendant) to pursue independently. ${ }^{58}$

This anomalous approach is not an isolated one, although it is found more frequently in the rarefied atmosphere of ethics opinions than in other concrete materials such as judicial opinions. ${ }^{59}$ Its functional defect is that a defense lawyer who feels compelled to follow the dictate of the City Bar opinion can readily frustrate its "public policy" objectives by advising his or her client that a lawyerless negotiation with the plaintiff60_or with the plaintiff's lawyer-could legally be conducted by a defendant or by any defendant's agents other than a lawyer and that one condition that could be insisted upon is a fee waiver by plaintiff's lawyer. If this analysis is valid, then the City Bar opinion rather pointlessly insists that a lawyer as agent may not do for a client what a client legally is entitled to accomplish without a lawyer's assistance.

The problem of imposing regulations upon lawyers, but not similarly constraining clients without lawyers, is a large and unsatisfactorily resolved one. Ethics opinions too often rest seemingly upon an entirely subjective view of gentility and good breeding or, equally dangerously, upon the "appearances of impropriety" that require lawyers to take-or, much more commonly, to refuse to take-otherwise lawful steps on behalf of a client. ${ }^{61}$ The unrealistic client-abnegating conduct that is called for in these opinions makes it highly unlikely that

58. A related, but different, objection is alluded to in the opinion. "The minority also urges that the ethical rule the Committee announces affects not only defense lawyers, but the defendants themselveswho are deprived of an opportunity to have their counsel seek a certain type of settlement which would limit the defendants' exposure." Id. at 511 . The majority's response is that the same thing happens under another provision of the MODEL CODE, supra note 6, DR 2-108(B), prohibiting settlements in which the lawyer agrees not to bring on behalf of other plaintiffs suits similar to the one being settled.

59. Finman \& Schneyer, The Role of Bar Association Ethics Opinions in Regulating Lawyer Conduct: A Critique of the Work of the ABA Committee on Ethics and Professional Responsibility, 29 U.C.L.A. L. REV. 67 (1981).

60. Direct negotiation between defense counsel and plaintiff would, of course, be impermissible without consent of plaintiff's lawyer. MODEL CoDe, supra note 6, DR 7-104(A)(1). 1983 MODEL RULES, supra note 6, Rule 4.2. Defense counsel is prohibited by language in this Disciplinary Rule from "caus[ing] another to communicate" with plaintiff, but this Rule probably does not preclude advice (without encouragement) that the defendant is entitled to make a direct approach to the plaintiff. In any event, the Prandini-extortion approach by defendant could be made directly to the plaintiff's lawyer. Defense counsel would, obviously, consent to the direct negotiation.

61. Notorious examples include the Watergate bugging opinion of the American Bar Association ethics committee. ABA Comm. on Ethics and Professional Responsibility, Formal Op. 337 (1974). This opinion stated that a lawyer could not "ethically" make a secret tape recording of a conversation with another person, including a nonparty witness, without that person's full consent after disclosure. From all that appears in Opinion 337, it would be unethical for a lawyer to make a tape recording of a terrorist's threat against a client unless the terrorist consented. ABA Comm. on Ethics and Professional Responsibility, Informal Op. 1320 (1975) took the rationale of Opinion 337 to one of its logical ends and opined that a lawyer's investigator was under a similar constraint. The original opinion acknowledged that much secret tape recording violates no law. The rationale of the opinion is quite unclear but appears to be based on a notion that the public mistakenly thinks that secret tape recording is always illegal and therefore that taping by a lawyer would be thought illegal. The opinion is criticized in Abramovsky, Surreptitious Recording of Witnesses in Criminal Cases: A Quest for Truth or a Violation of Law and Ethics.?, 57 TUL. L. REV. 1 (1982). For another view, see Finman \& Schneyer, supra note 59, at 116-17 (Opinion 337 may be based on notion that, unless lawyer indicates otherwise, any person wold assume that no tape recording is being made; secret tape recording without consent is arguably the kind of "dishonesty, fraud, deceit, or misrepresentation" proscribed in MODEL CODE, supra note 6, DR 1-102(A)(4)). 
they are actually widely observed. Or worse, they might be routinely ignored by some lawyers and adhered to by others. ${ }^{62}$ In the end, the "ethical" approach of the Association of the Bar of the City of New York fails because it is an unacceptable attempt to deal rationally and realistically with the problem. ${ }^{63}$

Lawyer fraud in asserting claims for fee awards under fee shifting need detain us only briefly. It will surprise no one to learn that lawyer chicanery, particularly when coupled with making false or misleading statements to a court, is proscribed. ${ }^{64}$ What is more problematical is whether such patent violations-and the less patent violations involved in other fee-shifting abuses by lawyers-are effectively controlled by the mechanisms of lawyer discipline.

\section{VI \\ "Ethical" Controls}

Because of peculiarities in the traditions and perhaps the imaginations of bodies that concern themselves with lawyer behavior, lawyer controls tend to be referred to as "ethical" controls. "Ethical" is employed not in the sense of ethics or moral philosophy but in the specialized sense that the formal sanctions for violation of ethical prescriptions are to be found within the arsenal of professional discipline. ${ }^{65}$ In this sense, to what extent can a public that is interested in the success of fee-shifting schemes be assured that lawyer discipline will effectively sanction those abuses of fee shifting that are violations of mandatory professional norms?

Unhappily, little reason exists to be optimistic that the lawyer discipline process can effectively sanction lawyer abuses of fee-shifting schemes. Consider, first, Prandini-sweetheart deals which involve excessive payments to the plaintiff's lawyer in return for the lawyer's undertaking to sell the settlement to the plaintiff. Unless the defendant has miscalculated, the sweetheart deal is a net advantage to defendant. Thus, effective enforcement is thwarted because the defendant, who is in the best position to detect and complain about the plaintiff's lawyer's conflict of interest, is the party who created the problem and seeks to profit from it. The real

62. The illogic of prohibiting lawyers from taking steps for clients that clients were legally entitled to take for themselves led to a major revision in an interim draft of the ABA Model Rules having to do with unilateral mistakes by an opposing party. See Hazard, The Lawyer's Obligation to Be Trustworthy When Dealing with Opposing Parties, 33 S.C.L. ReV. 181, 194 n.46 (1981).

63. The conclusion of the ethics committee is, however, supportable on very different grounds. See infra text accompanying notes 99-113.

64. MOdel CODE, supra note 6, DR 1-102(A)(4), 7-102(A)(3)-(6); see 1983 MOdel Rules, supra note 6, Rule 3.3(a)(1). Detected false statements in support of a request for fees are, understandably, treated with severity. E.g., In re Wolk, 82 N.J. 326, 413 A.2d 317 (1980) (disbarment for fraudulent misstatement to federal court in fee application statement).

65. This reflects a fading mindset. The new ABA Model Rules of Professional Conduct, for example, are explicit in their recognition that a great mass of applicable law applies to a lawyer's work beyond the rules of professional conduct. The mindset described here, however, still characterizes much of the work of bar ethics committees. A standard limit on their powers is that they may not consider questions of "law." See Opinions of the ABA Comm. on Professional Ethics 8, Rule 1 (1967) (Rules of Procedure of the Committee on Professional Ethics). The obvious implication is that their interpretations of professional norms, which is the only grist upon which their mill is permitted to grind, are not about "law." Of course, this is not so, and its falsity is occasionally implied in ethics opinions that state that lawyers may be formally disciplined for violation of mandatory professional rules. Mandatory rules are enforceable by legal sanctions through the process of lawyer discipline. 
victims of a sweetheart deal are the plaintiffs whose lawyers are bought off by the defendants, but they are in the worst position to detect the fraud because of an inability to understand, for lack of effective legal advice, that their part of the settlement is heavily undervalued. If a disgruntled client did complain to a lawyer discipline board, it is extremely unlikely that the board, with its typically heavy caseload and overburdened staff, would place a high priority on litigating (possibly relitigating) the complex issue of the fairness of the settlement and the fee given to the complaining party's lawyer.

With Prandini-extortion offers, the prospects for effective disciplinary response seem even more remote. First, it is debatable whether the defense lawyer's participation in the offer is a violation of professional rules. ${ }^{66}$ Second, an examination of actual situations reveals that defense lawyers are usually establishment lawyers and that establishment lawyers are very rarely brought before lawyer disciplinary agencies. ${ }^{67}$ Third, the Prandini-extortion arrangement will often be accompanied by an explicit agreement that the plaintiff's lawyer will accept a low fee or waive a fee altogether. ${ }^{68}$ Disciplinary agencies would probably regard a plaintiff's lawyer's complaint as the sour grapes afterthoughts of a lawyer who regretted an improvident agreement.

At the most fundamental level, lawyer disciplinary boards are very inactive on the question of lawyers' fee-charging practices. Despite the fact that many client complaints involve fee practices, ${ }^{69}$ disciplinary agencies bring few actions based on the professional rules relating to fees. ${ }^{70}$ The discipline that is meted out for feerelated offenses is typically found in the context of a multiple-count charge in which the fee overcharge seems lost in a crush of other flagrant offenses ${ }^{71}$ or in a situation where the overcharge is clumsily done, hopelessly large, or patently illegal. ${ }^{72}$ Beyond these exotica, the fee policing process seems to lack both subtlety and enthusiasm.

The failure of the lawyer disciplinary system to impose suitable constraints on lawyers' fee-charging practices can be explained on different grounds. It can be understood by those so convinced as additional proof of the conspiracy of the few against the many. ${ }^{73}$ This failure might furnish one more illustration of what happens when agencies that draft and enforce rules are closely aligned with and con-

66. See supra notes 55-63 and accompanying text.

67. Shuchman, Ethics and Legal Ethics: The Propriety of the Canons as a Group Moral Code, 37 GEO. WASH. L. REV. 244 (1968).

68. See supra text accompanying note 39.

69. E.g., Miller, Why Crooked Lawyers Go Free, READER's DiG., Sept. 1979, at 47, 52.

70. See, e.g., Marks \& Cathcart, Discipline Within the Legal Profession: Is It Self-Regulation?, 1974 U. ILL. L.F. 193, 213-14 (disciplinary agencies tend to regard all client complaints about fees, except for those charging fraud and overreaching, as outside the jurisdiction of the agency); Steele \& Nimmer, Lawyers, Clients, and Professional Regulation, 1976 AM. B. Found RESEARCH J. 917, 1012.

71. E.g., In re Finch v. State Bar, 28 Cal. 3d 659, 621 P.2d 253, 170 Cal. Rptr. 629 (1981); In re Marine, 82 Wis. 2d 602, 264 N.W.2d 285 (1978).

72. Florida Bar v. Samaha, 407 So. 2d 906 (Fla. 1981) (illegal fee); People ex rel. Cortez v. Calvert, 200 Colo. 157, 617 P.2d 797, 800 (1980) (excessive and illegal fee charged to client $A$ to advance adverse interests of client B). See generally Annot., 11 A.L.R.4TH 133 (1982).

73. E.g., Abel, Why Does the ABA Promulgate Ethical Rules?, 59 TEx. L. REv. 639 (1981). 
trolled by lawyers, the trade group that purportedly is being regulated. ${ }^{74}$ Free market ideology might be another explanation for a lack of disciplinary activity. Fee charging takes place in a great variety of ways and under many different individual arrangements between lawyer and client. Fee charges, for the most part, are regulated by market mechanisms-no doubt quite imperfectly because of low consumer levels of information, because of restrictions on the number of service providers, and, perhaps most importantly, because of apparent noncomparability of the service provided. Yet, despite market imperfections, there is at least the reason of dominant social view to leave most questions of pricing to the market.

Even if a disciplinary agency are disposed to pursue questions of fee overcharging vigorously, it would face the task of assigning a range of permissible values to fee charges that depend, legitimately, upon a long list of unweighted factors. ${ }^{75}$ The difficulty of making a multifarious determination of propriety is compounded further by questions of mens rea. The mens rea factor has not received adequate examination, and cannot here, but it seems clear that a standard of "guilty mind" is applied in bar disciplinary agencies and courts. Because of the highly stigmatizing nature of discipline, ${ }^{76}$ agencies are reluctant to impose sanctions unless they can be convinced that the lawyer's offense was the product of a subjective predisposition to act in antisocial ways. Consequently, one problem with finding this subjective antisocial predisposition when a lawyer charges a high fee is that greed, in some measure, is not widely regarded as a wrong in our society; indeed many think that a greedy motive or a similarly self-centered mechanism is the engine that drives the economy. ${ }^{77}$ Agencies are left with a preposterously compounded standard like "greedy greed"78 that the prosecutor will find difficult to satisfy.

The specific problem in fee shifting is not so much the size of the fee as the suspicion that the lawyer's conduct in the representation was influenced by an

74. E.g., Morgan, The Evolving Concept of Professional Responsibility, 90 HaRV. L. REV. 702 (1977); Wolfram, Barriers to Effective Public Participation in Regulation of the Legal Profession, 62 MINN. L. REV. 619 (1978). For an excellent survey and analysis of the values and conflicts implicit in self-regulation by the legal profession, see Rhode, Why the ABA Bothers: A Functional Perspective on Professional Codes, 59 TEx. L. REV. 689 (1981).

75. MODEL CODE, supra note 6, DR 2-106(B) (nonexhaustive list of eight factors); 1983 MODEL RulES, supra note 6, 1.5 (a) (same).

76. E.g., Cohen v. Hurley, 366 U.S. 117, 147 (1961) (Black, J., dissenting).

77. E.g., R. Posner, The Economics of Justice 88-115 (1981) (ch. 4: "The Ethical and Political Basis of Wealth Maximization"). Greed is, perhaps, a sloppy and argumentative way of saying something that can be more neutrally expressed, such as "preferences . . . backed up by a willingness [and ability?] to pay." Id. at 87.

78. See, e.g., MODEL CODE, supra note 6, DR 2-106(A) ("A lawyer shall not enter into an agreement for, charge, or collect an illegal or clearly excessive fee."); id. DR 2-106(B) ("A fee is clearly excessive when, after a review of the facts, a lawyer of ordinary prudence would be left with a definite and firm conviction that the fee is in excess of a reasonable fee."); see also CALIF. Rules of Professional Conduct, Rule 2 107(A) "A member of the State Bar shall not enter into an agreement for, charge or collect an illegal or unconscionable fee."); id. Rule 2-107(B) ("A fee is unconscionable when it is so exorbitant and wholly disproportionate to the services performed as to shock the conscience of lawyers of ordinary prudence practicing in the same community."); Rules Governing Disciplinary Proceedings, Rule 1.4(d), in 5 OKLA. STAT. ch. 1, app. 1-A (Supp. 1982) ("Controversies as to the amount of fees shall not be considered a basis for charges in a disciplinary proceeding unless it is made to appear that the amount demanded is extortionate or fraudulent."). 
impermissible conflict of interest that led the lawyer to take steps in the representation for reasons other than the best interests of the client. Here again, supervision of the lawyer's work would require a meticulous inquiry into a long and largely unverifiable course of conduct and would involve a quite unsatisfactory inquiry into the lawyer's motivations. These problems of proof make it highly unlikely that a lawyer disciplinary agency could operate very effectively in this area. Moreover, even if an agency could operate effectively, its inquiry could create an unseemly conflict with the courts involved in fee shifting.

The invocation of professional standards to restrain inappropriate lawyer behavior caused by fee-shifting arrangements is not limited to those adjudications by lawyer disciplinary agencies. Several courts have borrowed, for ill or for good, the fee-setting standards of the Code of Professional Responsibility as guides to judicial decisions concerning the size of fees. ${ }^{79}$ Whatever standard is employed, a common feature of all fee-shifting schemes is that the court in which the substantive conflict concerning the rights and liabilities of the lawyers' clients is resolved is the same tribunal that will set the size of the shifted fee if the parties do not settle the fee question. Typically, but not inevitably, as in some conflict-of-interest situations, the only party aggrieved by the size of a shifted fee is the party paying the fee or the party out of whose settlement fund the fee will first be taken. Any aggrieved party will naturally and necessarily first file a protest with the court that awarded the fee and seek a reduction or disallowance of the award. Then, most likely, a lawyer disciplinary agency will be asked to adjudicate the legitimacy of the lawyer's shifted fee only after a court has had an opportunity to assess the strength of any objections to the fee. The complaint, in effect, will attempt to place the lawyer disciplinary agency in the position of second-guessing the soundness of the original court's decision. The doctrine of collateral estoppel will not technically apply because the disciplinary prosecutor will not have been a party to the judicial fee dispute. ${ }^{80}$ But considerations of efficiency and economy still argue against a very extended jurisdiction to reexamine fee-shifting orders. Moreover, for one branch of the judicial system to sit in judgment on another branch outside the normal schemes for appellate review of orders ${ }^{81}$ seems both untidy and needlessly duplicative. If anything, there will be a higher burden of proof favoring the lawyer in the disciplinary proceedings ${ }^{82}$ so that optimism about systematically

79. The leading case is Johnson v. Georgia Highway Express, Inc., 488 F.2d 714, 717.19 (5th Cir. 1979). See also Parker v. Matthews, 411 F. Supp. 1059, 1067-68 (D.D.C. 1976), affd sub nom. Parker v. California, 561 F.2d 320 (D.C. Cir. 1977); Key v. Cascade Packing Co., 19 Wash. App. 579, 585, 576 P.2d 929, 933 (1978); Herro, McAndrews \& Porter v. Gerhardt, 62 Wis. 2d 179, 184, 214 N.W.2d 401, 404 (1974).

80. See generally Restatement (Second) OF Judgments § 34(3) (1982).

81. All state lawyers' discpline systems operate through mechanisms that provide for review in the state's judicial system, which is the same system that might have awarded the fee now challenged. The extreme case would be an attempt in a bar disciplinary proceeding to discipline a lawyer because of a fee award sustained by the state's highest court.

82. The customary burden of proof in a lawyer disciplinary proceeding requires proof of a violation by "clear and convincing" evidence. Comm. on Professional Ethics v. Bitter, 279 N.W.2d 521, 522 (Iowa 1979); In re Pennica, 36 N.J. 401, 419, 177 A.2d 721, 730 (1961); In re Marcus, 107 Wis. 2d 560, 576, 320 N.W.2d 806, 815 (1982) ("clear and satisfactory evidence"). At least one jurisdiction employs the "beyond a reasonable doubt" standard that is usually reserved for criminal proceedings. Rules and Regulations for 
more favorable outcomes is ill-founded.

\section{VII}

\section{Creating Proper Incentives}

Is there a better way, or will the system of fee shifting have to rely on the mercies of each individual lawyer's variant sense of personal integrity? Do the poor prospects for effective disciplinary enforcement mean that lawyers are beyond control in fee-shifting settings? With respect to the two Prandini problems, it is likely that ways can be found to deal with lawyer abuses of fee shifting. A solution can best be accomplished by structuring the procedures for fee shifting in ways that create incentives for appropriate lawyer behavior and provide nondisciplinary sanctions for inappropriate lawyer conduct.

Consider, first, the Prandini -sweetheart situation. The decision itself offered one solution-a ban on any discussion of the fee to be paid to the successful party's lawyer until the court had approved the settlement. ${ }^{83}$ Will this procedural solution work? Are its costs too high?

One of the commonly asserted objections to the Prandini-sweetheart solution is that it ignores the defendant's interest in knowing its total financial exposure in the event of settlement. ${ }^{84}$ The defendant, not knowing the size of the fee to be awarded to the prevailing party's lawyer, is in a poor position to assess its total economic exposure. Indeed, some fear that this uncertainty will result in far fewer settlements, thus unduly prolonging litigation and imposing unwanted burdens on crowded court dockets. ${ }^{85}$ Undeniably, the Prandini two-step settlement requirement leaves the defendant in the dark about total cost until the segregated question of fees is resolved. It is even theoretically possible that no subsequent fee settlement will be reached, resulting in extended litigation concerning the question of fees despite settlement of the underlying claim of the lawyer's client.

While this objection is not without substance, it can readily be overstated. The defendant typically will have some notion of the probable size of the court's award of attorney fees. In class actions, the court's own records might be available and might contain information about the number of hours worked by the opposing lawyer. ${ }^{86}$ Even in the absence of these records, the defendant's own expenditures

the Organization and Government of the State Bar of Georgia, Rule 4-221(e), $241 \mathrm{Ga} .643,760$ (1978). The customary standard in civil actions is the "preponderance" of the evidence standard. F. JAMES \& G. Hazard, Civil Procedure $\$ 7.6$, at 243 (2d ed. 1977). A substantial minority of courts apply this lesser standard in lawyer disicpline cases. E.g., In re Robson, 575 P.2d 771, 776-77 (Alaska 1978); In re McWhorter, 407 Mich. 278, 290, 284 N.W.2d 472, 478 (1979).

83. Prandini v. National Tea Co., 557 F.2d 1015, 1021 (3d Cir. 1977); see also supra note 32 and accompanying text.

84. E.g., A. Miller, supra note 33, at 222-23. The same objection cannot be made in shareholder derivative actions and similar class action types of litigation where the lawyer fee is paid out of a settlement fund, because the defendant's complete exposure is defined by the settlement figure. See PRINCIPLES OF CorPorate Governance, supra note $34, \S 7.07$, comment c at 413 .

85. A. Miller, supra note 33.

86. In class actions, courts that follow the recommendations of the Manual on Complex Litigation will have required the plaintiff's lawyer to submit periodic reports of hours worked. See MANUAL FOR COMPLEX Litigation $\S 1.47(1)$ (5th ed. 1982). These reports are to be under seal, presumably to avoid 
for legal fees will be some measure of the probable magnitude of the opposing lawyer's fee claim. The reported decisions on lawyer fees are now sufficiently numerous that some guidance on probable judicial reaction to requests for fee awards can be gained. No right to jury trial exists on the question of the size of a fee award, and thus reported judicial decisions give a much surer guide. ${ }^{87}$ Naturally, some part of the fee award is still indeterminate because of the large discretion that trial courts possess. Yet, most well-advised defendants will be able to determine the fairly narrow range within which a fee award will fall.

Another possible objection to the Prandini prohibition against presettlement fee discussions is that only ethical lawyers will abide by it. It still remains in defendants' interest to attempt to buy out opposing lawyers, and some plaintiffs' lawyers will perceive it as similarly in their interest to cooperate. The fear remains that strong economic incentives on both sides will predictably lead to collusive presettlement discussions despite the court ban. ${ }^{88}$ This consequence could follow if the Prandini solution is simply announced as a rule of professional conduct and its enforcement is left to lawyer disciplinary agencies. Enforcement would be difficult because the collusion would take the form of veiled communications, carefully designed to avoid creating concrete evidence of a violation of an ethical rule. Any conspirator tempted to blow the whistle must be aware that the evidence is equivocal and likely to be hotly contested. Also, the potential whistle-blower must realize that disclosure is likely to encourage the accused lawyer to counterattack. Not all lawyers have the kind of status and reputation which can resist and make hollow the threat of a retaliatory disciplinary charge. The whistle-blower also may confront the opposing lawyer in other litigation in which retaliatory moves could redound to the disadvantage of the whistle-blowing lawyer and his or her clients. If these and like constraints mean that only lawyers who internalize the Prandini standard, along with their clients, will be disadvantaged by the Prandini rule, then indeed the rule seems objectionable.

A short and inexpensive procedure, however, is available to make the Prandini prohibition against presettlement fee discussions more effective. Every judge presented with a first-stage Prandini settlement for approval should require that each lawyer involved in the settlement negotiations or any lawyer who later receives a part of the fee award file an affidavit describing in some detail the nature of the negotiations. The lawyer should be required to reveal the extent, if any, of discussions of fees, no matter how veiled. Many lawyers who might not hesitate to violate judicially stated requirements will quail at the necessity of denying under oath that they engaged in any offensive conduct. A lawyer who knows that an adversary can later demonstrate the falsity of his or her affidavit probably will regard that threat as too potentially destructive to risk the offensive conduct in the first place. Such a certification of compliance with a Prandini-like

divulgence of the plaintiffs' lawyers' work product. It seems desirable and consistent with this objective for the defendant to be permitted access to a summary of the records late in the initial settlement discussions.

87. The trial judge's findings of fact in support of a fee award are seldom disturbed on appeal. See generally 5A J. MOORE \& J. LuCas, MOORE's Federal Practice ף 52.03[1], at 2630 n.26 (2d ed. 1982).

88. See A. Miller, supra note 33, at $222 \mathrm{n} .39$ (survey of judges and lawyers indicates concern that Prandini might be impossible to enforce due to collusive avoidance of it). 
rule outlawing presettlement fee discussions has been proposed for inclusion in the American Law Institute's (ALI) recommendations for reform of shareholder derivative actions. ${ }^{89}$

If desirable for derivative actions, is the certificate of nonnegotiation of fees also desirable for all actions in which fee shifting is provided? Is the Prandini-sweetheart abuse limited only or mainly to class actions such as derivative suits? A Prandinitype certification procedure can be readily worked into the established procedural requirements for class actions and derivative suits because judicial approval is required before any of these cases can be dismissed or settled. ${ }^{90}$ Judicial approval, however, rarely is required for nonclass action suits and then is limited to representational suits such as actions on behalf of minors when special judicial solicitude is thought appropriate. ${ }^{91}$ Reasonable arguments can be made for the view that Prandini-sweetheart problems are largely limited to representational actions such as class actions and derivative suits. Representational suits are peculiar in that the lawyer has an unusually high degree of control over the disposition of the action. This power is justified by the absence, in a typical class action, of a significant interest on the part of any class member. But it is also a potential flaw in the design because, as discussed above, ${ }^{92}$ the absence of client control leaves the lawyer for the class free from any effective oversight. In contrast, it might be argued that in nonclass action suits there is significantly less need for substitution of judicial control. In these suits, the individual client can be relied upon to monitor the quality of his or her lawyer's representation, including those occasions when the lawyer recommends inadequate settlements for the client in return for a high fee shift.

Yet, empirical studies in nonrepresentational litigation give little assurance that client control is actually effective in many types of suits in which fee-shifting is found. ${ }^{93}$ For reasons developed by other papers in this symposium, the tendency is for many fee shifting schemes to operate primarily in favor of the litigational "untermensch"- persons whose lack of resources would normally bar them from court. ${ }^{94}$ These persons typically have little prior experience with lawyers and probably are sufficiently risk-averse to readily follow a lawyer's strong recommendation to accept a settlement. By definition, these clients will lack the resources and mobility to seek out a second opinion on the quality of their lawyers' advice. Consequently, one may conclude that judicial approval of settlements - together with an enhanced Prandini-like separation of settlement and fee negotiations such as tentatively proposed by the ALI study ${ }^{95}$ - should be applied in all fee shifting situations including those quite beyond class and other representational actions.

89. Principles of Cor porate Governance, supra note 34 at $\S 7.07$ (b) (i)-(iii) (Tent. Draft No. 1 , 1982).

90. FeD. R. CiV. P. 23(e) (class actions generally); FED. R. Civ. P. 23.1 (derivative actions).

91. E.g., Cal. Prob. Code $\$ 3500(\mathrm{~b})$ (West 1981) (court approval required for validation of settlement of minor's claim); N.Y. CIV. Prac. LAW $\S 1207$ (McKinney Supp. 1982) (same).

92. See supra text accompanying notes $24-25$.

93. Supra note 12.

94. Rowe, Predicting the Effects of Altomey Fee Shifting, Law \& ConTEMP. Probs., Winter 1984, at 139

95. Principles of CorPORATE Governance, supra note 34; see also text accompanying note 89 supra. 
At the least, incremental enactment of fee shifting in new areas should be undertaken only after consideration of the possible special utility of a requirement of judicial approval of settlements.

Prandini-extortion offers present a number of similarities and differences that require further attention. The prohibition in Prandini against presettlement discussions would limit but not eliminate the possible extortion problem. Under Prandini, the defendant presumably still has the opportunity, either directly or through defendant's lawyer, to make as part of the offer-but refuse to discuss-an express condition of waiver of plaintiff's entitlement to lawyers' fees. It is important to note that this move would not be available under the extended version of Prandini contained in the ALI proposal because the proposed language expressly outlaws "any agreement, negotiation or discussion concerning allowable plaintiff's fees or expenses with an opposing party in the action."96 The agreement itself, absent any discussion or negotiation, is proscribed. Unquestionably, once the "substantive" portion of the settlement offer is approved by the court, the leverage pressure is removed and nothing stands in the way of an arm's length negotiation between plaintiff's lawyer and the defense about the size of the lawyer's fee. Prandini cum ALI makes sense. Its costs, as discussed above, ${ }^{97}$ are tolerable and appropriate ones.

Prandini, however, is not universally accepted, and the ALI proposals are wending their way slowly through the cumbersome machinery of numerous committees and annual ALI meetings. There is little prospect that these proposals will be finally approved for some time. Pending the enactment of these proposals into law, is there any better approach for dealing with Prandini-extortion offers than that offered by the ethics committee of the Bar of the City of New York?98

Without regard to the language of the professional codes, three straightforward reasons exist for objecting to the conduct of a defense lawyer in making a Prandiniextortion offer. First, such conduct is extortionate and extortion is wrongful duress impermissible to both lawyers and nonlawyers. ${ }^{99}$ Second, lawyers and nonlawyers alike are prohibited by law from creating a conflict of interest that carries a substantial risk of harming the interests of the represented opponent. ${ }^{100}$ Third, Prandini-extortion agreements conflict with evident purposes of the fee-award statutes, which otherwise would allow fees, and thus these agreements should not be enforced because they offend public policy. ${ }^{101}$ In short, the position of the New

96. Principles of Corporate Governance, supra note 34 , at $\$ 7.07$ (b) (first sentence).

97. See supra notes $84-88$ and accompanying text.

98. See supra note 55 and accompanying text.

99. Cf. Carricarte v. State, 384 So. 2d 1261 (Fla.) (lawyer who tried to persuade marina developer to hire him for legal services through use of threats is guilty of felony extortion), cert. denied, 449 U.S. 874 (1980); Livermore, Lawyer Extortion, 20 ARIZ. L. REV. 403 (1978).

100. See generally Restatement (SECOND) OF AGENCy $\$ 312$ (1958) ("A person, without privilege, should refrain from causing an agent to violate a duty to a third party.").

101. The force of this third consideration depends upon the particular language, history, and purpose of the fee-shifting statute involved. For example, the purpose of the civil rights fee-shifting arrangement is, in major part, to encourage lawyers to bring such suits and thus to deter substantive violations of the civil rights acts. In that light, Prandini-extortion offers plainly conflict with the policy of the civil rights laws. See Shadis v. Beal, 685 F.2d 824 (3d Cir.), cert. denied, 103 S. Ct. 300 (1982). 
York City Bar prohibiting defense lawyers from participating in Prandini-extortion offers is correct, but for different and much more widely sweeping reasons than there suggested. These three reasons - which present criminal, fiduciary, and statutory policy perspectives on the same problem-can best be understood in the context of the quandaries confronting a plaintiff's lawyer who meets a Prandiniextortion offer head-on.

Consider a recent housing discrimination case in which the plaintiffs primarily sought injunctive relief against a municipality. ${ }^{102}$ After months of motions, discovery, and other preliminary skirmishes, all requiring substantial expenditures of lawyer time, the plaintiffs were presented with an offer by the defendants. The offer, if accepted, would have conceded the objectives of the plaintiffs' suit at a time when financing and housing subsidies were still available. Delay could have jeopardized everything because even success at an eventual trial might have found the then-available financing arrangements so altered that the relief accorded would be a mere fraction of that offered by the proposed settlement. The only hitch was the Prandini-extortion condition: plaintiffs' lawyers must agree to waive all of their fee. What are the options?

First, most obviously, motivation to receive a fee for already extensive and uncompensated legal services might lead the plaintiffs' lawyers to urge the plaintiffs to reject the settlement offer. Clearly this action is unethical because the settlement is in the best interests of the clients and the lawyers' self-interested advice would be seriously defective. ${ }^{103}$ Nonetheless, by attaching the Prandini-extortion condition to the offer, a defendant clearly increases the risk that a settlement very favorable to the plaintiffs will be rejected because of defective advice from lawyers who succumb to the pressure of a possible fee shift that could occur if relief is obtained at trial.

Second, the lawyers could collectively sigh and accept the deprivation of a fee without further protest or with only the symbolic protest of a complaint to a professional disciplinary agency. Such resignation seemingly would have the inevitable effect of limiting lawyers' economic ability to accept civil rights cases in the future. This result, given the statutory policy clearly expressed in the Civil Rights Attorneys' Fee Awards Act, ${ }^{104}$ would be quite dysfunctional to the objectives of

102. Chattanooga Branch of the NAACP v. City of Chattanooga, Nos. 82-5016/5013 (6th Cir. 1982) (appeal dismissed). I am indebted to my fellow Duke conferee E. Richard Larson for the reference to the Chattanooga NAACP problem.

103. Difficult and subtle issues lurk here. For example, the lawyers might believe-"objectively"that victory in the case would be truly Pyrrhic as far as the plaintiff class is concerned, because the Prandini device would deprive its members of needed representation in the future. Under these facts, it is arguable that the lawyers, in good faith, could urge rejection of the settlement. But this is not entirely clear as evidenced by two reasons from the Chatlanooga NAACP case. The lawyers for the plaintiffs were supported, in part, by advocacy organizations which derive financial support from contributions, and thus the impact on them of a Prandini-extortion condition was perhaps less than that which would be visited on an individual lawyer. Second, the broad scope of the relief that the settlement afforded the plaintiff class made any cost-benefit calculation tilt rather strongly in favor of accepting the settlement. For a thoughtful discussion of some of the lawyer-class difficulties that settlement offers can entail, see Rhode, supra note 39 , at $1204-15,1237$.

104. 42 U.S.C. $§ 1988$ (Supp. 1977). 
encouraging full and vigorous representation in civil rights suits and of providing economic deterrence to civil rights violators.

Third, beyond these unacceptable or unfortunate results lie possible moves by the class lawyers to obtain advance judicial protection. Suppose that the plaintiffs' lawyers invoke the protection of the trial court. The theory behind this move is to obtain the protection of a Prandini order from the trial court directing the defendant to excise the fee-frustrating condition from the settlement offer and to avoid any fee discussions during negotiations. But this clearly is a dangerous gambit. If the court grants the requested relief, ${ }^{105}$ the defendant in most instances is perfectly free to walk away from the settlement-to the obvious detriment of the plaintiff class. Indeed, this power of defendants to insist upon fee-waiver conditions depends heavily on the take-it-or-leave-it power that withdrawal of the settlement offer portends. Again, the threat to the plaintiff class' interest in achieving the settlement seems to militate against such a move by the plaintiff's lawyer.

Fourth, plaintiffs' lawyers can consider a bit of hardball in return. One possible gambit runs along the following lines. The settlement offer is accepted by the class and their lawyers with the lawyers privately memorializing their pain and outrage at being euchred into a fee waiver by the force of the leverage applied by the defendant. The class' interests are protected by entry of a judgment locking the defendant into a res judicata-protected final judgment. When this protection is assured, the disenchanted lawyer can take one of several possible moves to attack the fee-waiver condition of the settlement and obtain an adequate award. This can be done, most obviously, by either a postjudgment motion for fees in the same court that entered the judgment on the settlement on a theory that is briefly outlined below. This possible strategy for springing out of the trap set by the defendant is fraught with uncertainty.

The postjudgment motion strategy is derived from the Supreme Court's decision in White v. New Hampshire Department of Employment Security. ${ }^{106}$ The Court there held that a postjudgment motion for attorney fees is not governed by the ten-day time limitation of the federal procedural rules governing motions for altering or amending a judgment. ${ }^{107}$ Unhappily, however, the majority refused to reveal what other possible time limitations may apply ${ }^{108}$ or whether general equitable standards of fairness and avoidance of prejudice to the defendant are the only limitations. ${ }^{109}$ The obvious reason for the class' lawyer to wait is to permit the tenday time limits for direct attack upon the judgment to expire before raising the question of fees. 110 Expiration of the ten-day period makes it less likely that the

105. In the actual case, the trial court refused to grant the requested Prandini order for undisclosed reasons. The court did not, however, formally rule on the motion. See Brief for Appellants (Plaintiffs) at 7 , Chattanooga Branch of the NAACP v. City of Chattanooga, Nos. 82-5016/5013 (6th Cir. 1982). The Sixth Circuit had neither adopted nor rejected Prandini. Also, this case is factually distinguishable from Prandini in that a "buy out" of the plaintiffs' lawyers was not threatened.

106. 455 U.S. 445 (1982).

107. Id. at 450-54; see FED. R. CIV. P. 59(e).

108. Justice Blackmun complained in a concurring opinion about the wastefully incremental approach of the majority. 455 U.S. at 455-56 (Blackmun, J., concurring).

109. See id.

110. See FED. R. CIV. P. 59(b), 59(e). 
defendant could reopen the judgment to the detriment of the client. ${ }^{111}$ A firmer basis for protection takes the form of an express condition in the lawyer's request for relief to the effect that the lawyer will abandon the request if the client's settlement would be upset by grant of the requested relief.

The substantive thrust of the lawyers' motion to set aside the fee waiver and to award fees as provided in the fee-shifting statute rests upon the ground that the fee-waiver provision of the agreement is void because it is contrary to public policy. ${ }^{112}$ Under the circumstances of the housing discrimination case, plainly, the question of the validity of a purported contractual waiver of a federal statutory right to a fee is decided exclusively under federal standards. ${ }^{113}$ Because federal law providing for an award of attorney fees in civil rights cases is so plainly frustrated by Prandini-extortion offers, coerced waivers of this kind should not be upheld.

Analytically, the lawyer's postsettlement request for fees is founded directly upon the fee-shifting statute. Thus, the general absence of a tort action for duress $^{114}$ is irrelevant. The lawyer's earlier assent to waive the fee shift enters the case as a defense by the defendant to the claim for fees. The lawyer's argument is that the assent was coerced and that, as a result, the fee waiver should be an ineffective barrier to a fee request. The plaintiff's lawyer's agreement to the Prandini extortion fee condition, while planning all along to attack it later, should not constitute an estoppel. On the whole, courts have been unreceptive to such estoppel claims when a strong argument is made for voiding a contractual term on public policy grounds. ${ }^{115}$ Plainly, no superior access to the facts or legal basis for invalidating the fee-waiver condition exists, and the defendant should have looked only to its defense lawyer for advice on the validity of the waiver.

The unenforceability of promises on the ground of public policy is a large topic which this article cannot examine in satisfactory detail. ${ }^{116}$ Illustrative of the approach that might be taken in Prandini-extortion situations is the recent decision of the Third Circuit in Shadis $v$. Beal, ${ }^{117}$ which invalidated a very similar contractual provision. The court there struck down on public policy grounds a provision of a contract between the Commonwealth of Pennsylvania and a legal services

111. After expiration of the ten-day period following entry of a judgment, the federal rules permit judgments to be set aside only on narrow grounds. See FED. R. CIV. P. 60. See generally, 6A J. MOORE, Federal Practice |f 60.02 (2d ed. 1983); 7 id. If 60.22[2], at 60-182 to 184.

112. See generally Restatement (SECOND) OF CONTRACTS \$ 178(1) (1981): "A promise or other term of an agreement is unenforceable on grounds of public policy if legislation provides that it is unenforceable or the interest in its enforcement is clearly outweighed in the circumstances by a public policy against the enforcement of such terms." See also, e.g., A. Corbin, Contracts, $\$ 1375$ (1962 \& C. Kaufman Supp. 1982); E. FARnSwORTH, Contracts $\$ \S 5.1-.9$ (1982).

113. See Shadis v. Beal, 685 F.2d 824, 828 (3d Cir. 1982); see also Dice v. Akron, C. \& Y. R.R., 342 U.S. 359 (1952) (validity of release of liability under Federal Employers Liability Act governed by federal common law).

114. See generally E. FARnsworth, supra note 112, § 4.9, at 233-34 n.5 (1982). Voiding the fee-waiver promise on the ground of economic duress would be an alternative approach to the "public policy" ground advanced here. Duress as a defense to a contractual claim is well recognized. Id. at $\S 4.9$.

115. E.g., Inter-Continental Promotions v. Miami Beach First Nat'l Bank, 441 F.2d 1356, 1360-61 (5th Cir.), cert. denied, 404 U.S. 850 (1971).

116. For general treatment, see, e.g., authorities cited supra note 112.

117. 685 F.2d 824 (3d Cir.), cert. denied, 103 S. Ct. 300 (1982). 
organization under which the organization agreed not to request legal fees in actions against the state in return for basic funding of its operations. The court refused to permit the state "to vitiate by contract a significant portion of the power and duty which Congress has granted to the judiciary as an essential tool in the scheme of civil rights enforcement." 18 A private contract to waive fees in Prandiniextortion circumstances seems equally contrary to the public policy goals of Congress.

A question raised by this analysis is whether voiding the fee-waiver clause of the settlement contract should bring down the entire settlement, including the portion of the settlement favorable to the client of the lawyer victimized by the Prandini-extortion fee waiver. The courts' general approach is to invalidate the entire contract only when the offending clause is an integral part of the contract and its excision makes the remainder of the contract impossible or seriously difficult to perform. ${ }^{19}$ This approach normally leaves the substantive part of the settlement entirely unaffected by a determination that the Prandini-extortion fee waiver is invalid. Doctrinally, the fee award is treated as independent from the merits for several purposes, such as appeal. ${ }^{120}$ Practically, it is inconsequential that the defendant might claim that the fee waiver was a "but for" portion of the settlement offer. Defendant's intent to gain a significant advantage by means of the forbidden contractual term plays no part in determining its severability from the rest of the contract which, in any event, is now embodied in a judgement.

The invalidity of the fee-waiver clause on public policy grounds is, of course, an argument that can be made directly against the defendant. Thus, unlike the situation that might arise under the New York City Bar ethical opinion, ${ }^{121}$ the defendant is bound by the same legal rules as those that shackle defense counsel. Moreover, because the fee-paying party is not legally entitled to insist on a Prandini-extortion fee waiver, the professional rules that prohibit a lawyer from assisting a client in performing an illegal or fraudulent act ${ }^{122}$ or counseling a client to disobey a court order ${ }^{123}$ are also applicable. Much more convincingly than the approach of the City Bar, these rules prohibit the defense lawyer's initial participation in the offer.

118. Id. at 831 .

119. Restatement (SEcond) of Contracts $\$ \$ 178-84$ (1976).

120. See supra note 29.

121. See supra note 55 , notes $58-63$ and accompanying text.

122. MOdel Code, supra note 6, DR 7-102(A)(7); 1983 Model Rules, supra note 6, Rule 1.2(d); e.g., Louisiana State Bar Ass'n v. Weinstein, 416 So. 2d 62 (La. 1982). Somewhat more problematic is the question whether a lawyer's advice or assistance to a client to commit a tort or a breach of contract is sanctionable as unprofessional. See, e.g., Silver v. George, 1 Hawaii App. 331, 618 P.2d 1157 (1980), affd, 64 Hawaii 503, 644 P.2d 955 (1982) (lawyer who drafted usurious note committed per se violation of duty, thus making him liable to nonclient payee of note). Compare Probert \& Hendricks, Lawyer Malpractice: Duty Relationships Beyond Contract, 55 NOTRE Dame Law. 708, 720-21 (1980) (lawyer's exposure to liability to injured third parties is least in the case of an advised breach of contract, questionable in the case of a contemplated tort with greater likelihood of liability if the tort is one involving intentional fraud (such as misrepresentation), and greatest if the client's intended act is also a crime), with Schwartz, The Professionalism and Accountability of Lawyers, 66 CALIF. L. REV. 669, 671 (1978) (as a disciplinary matter, lawyers should be prohibited from aiding clients in the commission of any tort).

123. E.g., Davis v. Goodson, 276 Ark. 337, 635 S.W.2d 226 (1982), cert. denied, 103 S. Ct. 798 (1983); Committee on Professional Ethics v. Crary, 245 N.W.2d 298, 307 (Iowa 1976). 
By force of the contract doctrine invalidating settlement terms that are opposed by strong public policy, the policies of fee-shifting arrangements can be vindicated in ways that are straightforward and permit no evasion. Unlike leaving manipulation of the fee-shifting statute to the uncertain vagaries of enforcement through disciplinary agencies, the public policy approach also has the merit of eliminating the defendant's economic motivation to engage in the tactic. As with similar approaches taken to solve the problem of other lawyer abuses, the public policy approach seems much more fruitful than reliance on disciplinary enforcement. Professor John Leubsdorf, for example, has urged that contingency factors in fee awards be reformed. One reason for this reform is to avoid a potential conflict of interest between client and lawyer that exists because of the temptation forced upon the lawyer to attempt to maximize his or her fee by emphasizing the weaknesses of the client's case at a time when there is a possibility of an upset of the settlement. ${ }^{124}$ To the extent that fee-shifting awards employ factors that invite conflicts of interest in a significant number of cases, and to the extent that these schemes can readily be replaced by others, it is sensible to resort to other methods of computation that do not create lawyer-client conflicts. It is preferable to strengthen the fee-award mechanisms rather than trust the lawyer disciplinary agencies to perform the difficult task of attempting to identify situations in which a lawyer has fallen prey to the tempting conflict. ${ }^{125}$

\section{VIII}

\section{Conclusion}

Fee-shifting schemes can offer powerful incentives to lawyers to pursue their own interests at the expense of client interests. These schemes can also be frustrated by manipulation. Effective client control is typically absent. Disciplinary agencies are ill-designed to serve as surrogate clients with more effective control. Clearly, decisions by plaintiffs and defendants about levels of expenditures on legal fees cannot be treated as endogenous continuous variables in a model of fee shifting with pretensions of wide applicability and great power. ${ }^{126}$ To date, however, no account that acknowledges the independent variability of lawyer control has proposed a decision model that fully and adequately accounts for this problem. ${ }^{127}$ Nonetheless, in light of present understanding of lawyer and client motivations, fee reformers should guard against designing fee-shifting arrangements that create significantly differing interests between lawyers and clients that

124. See Leubsdorf, supra note 17 , at $482-85$.

125. The specific reform proposed by Professor Leubsdorf is to create set contingency bonuses for different groupings of cases. This method would effectively remove any temptation for a lawyer in such cases to argue the weakness of the client's case and would cure other anomalies as well. See id. at 502 .

126. I nonetheless applaud Bruce Owen's much more carefully limited and refreshingly modest economic analysis of fee shifting in this symposium. See Braeutagam, Owen \& Panzar, An Economic Analysis of Altemative Fee Shiffing Systems, LAW \& ConTEMP. Probs., Winter 1984 at 173. As Mr. Owen takes pains to point out himself, his model is limited by his inability at this point to relax assumptions about client control over critical decisions. Mr. Owen's model at least supplies a highly suggestive beginning toward an economic account of fee shifting. A complete understanding, however, awaits a model that takes adequate account of lawyer motivations as an exogenous effect.

127. See R. Posner, Economic Analysis of LAW 434-41 (2d ed. 1977); Shavell, supra note 4. 
are exploitable either by uncontrolled fee seekers or by adversaries seeking to exploit advantages for their own clients.

No real-life system of fee shifting can hope to remove all traces of economic conflict between lawyer and client. Some form of these conflicts will always inhere in the fact that a lawyer has values, beliefs, opportunities, experience, costs, and other pressures that differ from those of the client. It seems clear, however, that more can and should be done to protect vulnerable clients from the most ravaging forms of lawyer disloyalty and to protect faithful lawyers from serious and dysfunctional sacrifices imposed by their adversaries. 